\title{
Restricted Geographic Sampling Yields Low Parasitism Rates but Surprisingly Diverse Host Associations in Avian Lice (Insecta: Phthiraptera) from South Texas
}

\author{
John P. Pistone ${ }^{1}$, Jessica E. Light ${ }^{1}$, Tyler A. Campbell ${ }^{2}$, Therese A. Catanach ${ }^{3}$ and Gary Voelker ${ }^{1, *}$ \\ 1 Department of Ecology and Conservation Biology, Texas A\&M University, College Station, TX 77845, USA; \\ johnppistone@gmail.com (J.P.P.); jlight2@tamu.edu (J.E.L.) \\ 2 East Foundation, 200 Concord Plaza Drive, Suite 410, San Antonio, TX 78216, USA; \\ tcampbell@eastfoundation.net \\ 3 Ornithology Department, Academy of Natural Sciences of Drexel University, Philadelphia, PA 19103, USA; \\ tacatanach@tamu.edu \\ * Correspondence: gvoelker@tamu.edu
}

check for

updates

Citation: Pistone, J.P.; Light, J.E.; Campbell, T.A.; Catanach, T.A.; Voelker, G. Restricted Geographic Sampling Yields Low Parasitism Rates but Surprisingly Diverse Host Associations in Avian Lice (Insecta: Phthiraptera) from South Texas. Diversity 2021, 13, 430. https:/ / doi.org/10.3390/d13090430

Academic Editor: Juan Carlos Illera

Received: 16 August 2021

Accepted: 2 September 2021

Published: 7 September 2021

Publisher's Note: MDPI stays neutral with regard to jurisdictional claims in published maps and institutional affiliations.

Copyright: (c) 2021 by the authors. Licensee MDPI, Basel, Switzerland. This article is an open access article distributed under the terms and conditions of the Creative Commons Attribution (CC BY) license (https:// creativecommons.org/licenses/by/ $4.0 /)$.

\begin{abstract}
South Texas is a highly variable region encompassing multiple habitat types and harboring a wide diversity of organisms. However, the parasite fauna in this region is poorly known, especially for avian ectoparasites such as lice. To better understand avian louse diversity and host associations in South Texas, we examined a total of 507 birds for chewing lice. Lice were morphologically identified to genus and phylogenetic analysis was performed using one mitochondrial (COI) and two nuclear (18S rRNA and EF-1 $\alpha$ ) genes. Of the birds examined, 69 (13.5\%) were parasitized by lice resulting in a total of 63 host associations across 45 bird species, 29 of which were previously unrecorded. The predominant taxa encountered during this study included two of the most diverse louse genera, Myrsidea and Brueelia. Molecular analyses revealed 21 distinct genetic lineages, 17 of which are associated with novel host associations and may represent new species. This study represents the first extensive examination of avian louse host associations and relationships in Texas and reveals that there is still much to be learned about ectoparasite diversity in the New World.
\end{abstract}

Keywords: avian lice; birds; chewing lice; ectoparasites; genetics; parasitism

\section{Introduction}

Chewing lice (Insecta: Phthiraptera) are small, dorsoventrally flattened ectoparasites found on numerous bird and mammal species [1,2]. Avian chewing lice are placed into two suborders, Amblycera and Ischnocera. Ischnocerans are feather specialists (feather lice) feeding on feathers and dead skin. Amblycerans have a similar diet, but some also feed on blood or body fluid secretions [3]. Each suborder is characterized by distinctive morphologies, and they partition the avian body based on feeding strategy and host preening avoidance [4]. Lice are obligate, permanent parasites that spend their entire life cycle (egg, nymphs, and adults) on their host (i.e., there is no free-living stage to the life cycle [5]). However, chewing lice can move among hosts via two main methods of transport: vertical transmission from parent to offspring, and horizontal transmission via phoresis ("hitchhiking") on hippoboscid flies [1,6,7]. Although phoresis is not uncommon, it is more frequently used by ischnoceran than amblyceran lice $[1,7,8]$. This method of transmission may allow lice to escape competition from other lice on the same host and potentially encounter a novel host [8]. Despite the ability to switch hosts (should the opportunity occur), many louse species are highly specialized to one host species [2]. However, some louse species and genera can be host generalists, parasitizing multiple host species over a large geographic area. Sometimes these host generalists may represent cryptic species [9], but many times these lice simply have wide host and geographic associations. Close morphological examinations as well as genetic assessments of lice are needed to better 
understand host associations, louse relationships, and to determine if generalist species are harboring cryptic species or simply have a widespread host and geographic range.

Several studies have investigated the louse associations of avian species in North America. Exemplar studies include examination of ectoparasites from Wild Turkey ( $M e-$ leagris gallopavo) in California [10], community structure of lice on the Western Scrub Jay (Aphelocoma californica) in the Southwestern United States [11], phylogenetic relationships of lice on Catharus thrushes in Illinois [12], and louse-host associations of dove species in Manitoba, Canada [13]. Except for a few studies examining population genetics, parasitism rates, and host switching of chewing lice parasitizing doves [14-16], there have been few studies that have examined louse relationships in Texas. This is surprising as Texas and especially South Texas, is highly diverse in terms of habitats and vertebrate fauna [17]. As such, Texas is not unlike Mexico and Central America in being an understudied area with respect to understanding louse-host associations. For example, several studies in Mexico have examined co-evolutionary processes and speciation of chewing lice parasitizing birds, but these have been limited to dove species $[9,14,18]$. In Central America, only a few studies from Costa Rica [19-21] and Panama [22] exist, but these primarily provide descriptions of new louse species rather than descriptions of host associations and louse diversity.

Given these limited studies, many questions remain unanswered about the biogeography, host associations, and genetic relationships of avian chewing lice across a significant portion of North America. The objectives of this study are to assess louse-host associations and louse diversity, and to construct molecular phylogenies to determine relationships among lice collected from birds surveyed in South Texas.

\section{Materials and Methods}

\subsection{Louse Sampling and Identification}

Chewing lice were collected from birds intermittently during 2013-2015 on two East Foundation (eastfoundation.net) ranches located in southern Texas (Figure 1). These East Foundation properties occupy approximately 71,200 hectares of land in Jim Hogg, Starr, Willacy, and Kenedy Counties. For this study, samples were obtained from San Antonio Viejo Ranch (60,298 hectares located inland in Jim Hogg and Starr Counties) and El Sauz Ranch (10,926 hectares located coastally in Kenedy and Willacy Counties; Figure 1). While the two ranches are generally similar in terms of dominant vegetation, El Sauz has extensive sand sheets, ephemeral ponds, and receives ca. $10 \mathrm{~cm}$ more rain annually (30-year Normals via [23]) as compared to San Antonio Viejo. The avifaunal composition of the two ranches is effectively the same in terms of resident and wintering species, although El Sauz appears to have a greater number of Neotropical migrants passing through, likely due to its coastal location (JPP pers. obs.).

Birds were captured in the field via mist net during all seasons. Some birds were released, and others were euthanized and prepared as voucher specimens and deposited in either the East Foundation's collection or at the Biodiversity Research and Teaching Collections (BRTC) located at Texas A\&M University (TAMU; according to TAMU Animal Care and Use Permits IACUC 2012-6 and 2015-0020). In both instances, birds were ruffled for chewing lice using a toothbrush to thoroughly brush the feathers over collecting paper, with a new piece of paper being used for each bird [24,25]. All ectoparasites were transferred to a collection tube. The birds that were released were dusted with flea powder (Zodiac ${ }^{\circledR}$, Schaumburg, IL, USA) to aid in releasing ectoparasites from their plumage; birds were ruffled prior to release [26]. Each euthanized bird was placed in its own individual bag with a cotton ball dipped in ethyl acetate, which acts as a fumigant to release the lice from their host [25]. After several minutes of exposure to ethyl acetate, birds were ruffled, and lice transferred to a collection tube as above. After lice were collected from a bird, they were stored either dry or in ethanol at $-80^{\circ} \mathrm{C}$. 


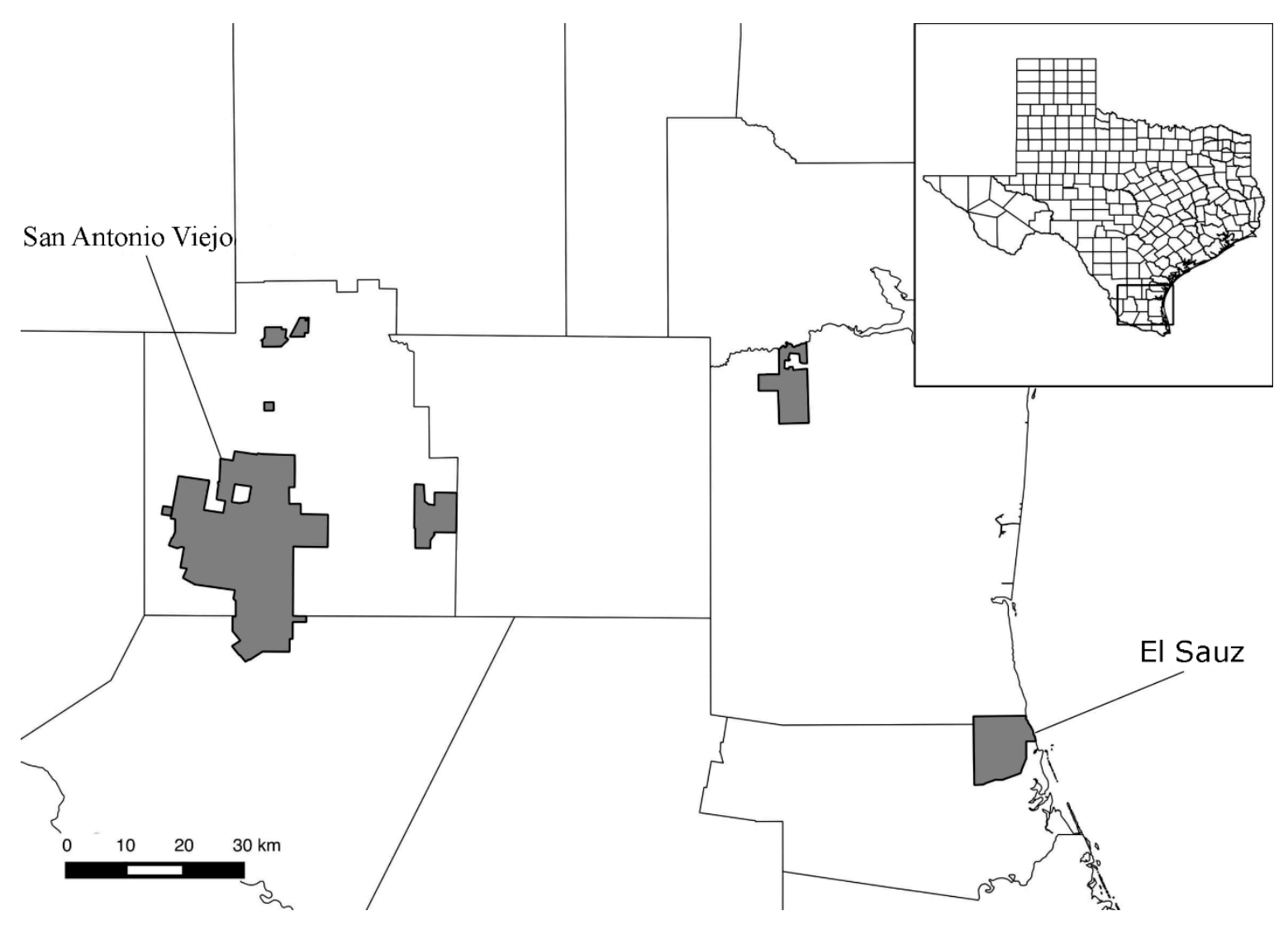

Figure 1. Map of Texas, with an emphasis on south Texas and all East Foundation properties (shaded regions). The two properties for this study (San Antonio Viejo and El Sauz) are indicated.

Digital vouchers were created before DNA extraction (below) for each chewing louse by using an Olympus SZX10 microscope, Intralux 6000 light source and SPOT v4.6 software (2009 Diagnostic Instruments). Following DNA extraction, specimen exoskeletons were retained, cleared, and mounted on a microslide in balsam as vouchers, following general protocols [27]. We used a combination of published keys, taxonomic descriptions, and previously identified vouchers with molecular data to identify our specimens to the lowest taxonomic level possible.

We used Price et al. [2] to identify our specimens to genus and to determine chewing louse species that were previously recorded from the host species in question. We elected not to make species determinations based solely on published host records. This is partially due to the fact many hosts are poorly sampled, particularly in the geographic region we focused on. It is also possible that multiple congeneric lineages of lice exist on a single host species in different portions of the range [28] leading to erroneous identifications. When possible, we used louse species identification keys, but in most instances, we relied primarily on original descriptions and revisions. Specifically, we utilized the works of Carriker [29], Clay [30,31], Dalgleish [32], Emerson [33,34], Grossi et al. [35], Kellogg [36], Osborn [37], Price [38,39], and Williams [40] to identify our specimens. Although we attempted to identify every voucher, in some instances, our specimens were not able to be identified with confidence. This included instances where nymphs were sequenced or if the voucher was missing structures required for identification. In some cases, multiple samples representing the same louse species were sequenced. In these cases, other vouchers were identifiable, and that identification was applied across all samples. In a few instances, published papers included species level identification of their sequenced louse samples. In instances where our sequence data indicated we had conspecific lice in our sample, we included these identifications. In the remaining instances, we left the species identification undetermined, regardless of if there was a published host 
association between the louse genus and the host species. No identification was made based exclusively on host-parasite relationship.

\subsection{DNA Extraction, Amplification, and Sequencing}

DNA extraction was performed using the E.Z.N.A. ${ }^{\circledR}$ Tissue DNA Kit (Omega Bio-Tek Inc., Norcross, GA, USA) following louse specific protocols [41]. Before the extraction began, the chewing lice were washed in 1X phosphate-buffered saline solution to remove possible contaminants from the specimen. After the wash, the abdomen of the louse specimen was sliced using a sterile surgical blade. The manufacturer's extraction protocol was followed throughout the process, except the total DNA elution volume was lowered to $70 \mu \mathrm{L}$ ( $35 \mu \mathrm{L}$ per elution). Upon completion of DNA extraction, each louse exoskeleton was preserved in ethanol and stored at $-80^{\circ} \mathrm{C}$ to be retained as a voucher specimen at the Texas A\&M University Insect Collection.

Polymerase chain reaction (PCR) was performed to amplify a portion of the mitochondrial cytochrome c oxidase subunit I (COI) gene, as well as a portion of the nuclear $18 \mathrm{~S}$ ribosomal RNA (18S) and elongation factor- $1 \alpha(\mathrm{EF}-1 \alpha)$ genes. We used primers L6625 and H7005 to isolate COI [42], NS1 and NS2a for 18S [43], and EF1-For3 and Cho10 for EF-1 $\alpha$ [44]. Amplification protocols for COI and EF-1 $\alpha$ genes were followed as described in Light et al. [45] and for the $18 \mathrm{~S}$ protocol as described in Light et al. [46]. We amplified COI for all samples from which DNA was isolated, while amplifications of $18 \mathrm{~S}$ and $\mathrm{EF}-1 \alpha$ were performed for a subset of taxa that represented individual clades recovered in the COI phylogenies. The amplified PCR products were electrophoresed with $2 \mu \mathrm{L}$ of 100 bp Promega DNA ladder (Applied Biosystems) on an agarose gel to determine PCR success. Successfully amplified PCR products were purified using ExoSAP-IT (United States Biochemical Corporation, Cleveland, OH, USA) and sent to Beckman-Coulter Genomics (Danvers, MD, USA) or Yale University (New Haven, CT, USA) for sequencing in both forward and reverse directions using the PCR primers. Forward and reverse strands were edited and combined using Sequencher v.4.2.2 (Gene Codes Corporation, Ann Arbor, MI, USA). Sequences were then aligned using MUSCLE [47] and verified by eye. Sequences are available on GenBank (Table S2).

\subsection{Sequence Analyses}

Each chewing louse sequence was compared to published sequences located in GenBank by using the Basic Local Alignment Search Tool (BLAST). Closely related sequences resulting from the BLAST search (Table S1) were added to our data set for phylogenetic analyses. Phylogenetic analysis for COI occurred in two separate analyses: one for the suborder Amblycera and one for the suborder Ischnocera. Each analysis used two specimens from the louse suborder Anoplura as outgroups (Fahrenholzia zacatecae and Haematopinus eurysterunus; Table S1). Analysis of the nuclear genes, $18 \mathrm{~S}$ and EF- $1 \alpha$, was performed for each gene separately but with Amblycera and Ischnocera combined in each analysis. In addition to these individual gene analyses, four different analyses were performed combining genes to assess louse relationships: two using mitochondrial and nuclear genes (COI+18S, COI+EF- $1 \alpha)$, one assessing only the nuclear genes $(18 \mathrm{~S}+\mathrm{EF}-1 \alpha)$, and one analysis combining all genes $(\mathrm{COI}+18 \mathrm{~S}+\mathrm{EF}-1 \alpha)$ using concatenated data sets. Phylogenetic analyses of these combinations of genes were performed to illustrate how the more rapidly evolving COI gene was driving tree topology. Amblycera and Ischnocera were combined in each of these four combined gene analyses. Although we were not able to amplify all genes for all taxa and many GenBank specimens did not have all three genes available (Tables S1 and S2), we included all specimens and their available data in each phylogenetic analysis.

Prior to phylogenetic analysis, PartitionFinder v2.1.1 [48] was used with the Bayesian information criterion to select the appropriate number of partitions and model of evolution at each partition for each gene. The same partitions and models of evolution identified in the single gene data sets were used in the combined gene analyses. For both protein coding genes, three partitions were selected, one for each codon position (COI: $H Y K+G$, 
GTR $+\mathrm{I}+\mathrm{G}$, and GTR+I+G; EF-1 $\alpha$ : $\mathrm{K} 80+\mathrm{I}+\mathrm{G}, \mathrm{SYM}+\mathrm{I}+\mathrm{G}$, and $\mathrm{K} 80+\mathrm{I}+\mathrm{G}$, for the first, second, and third codon positions, respectively), whereas only one partition was selected for $18 \mathrm{~S}$ $(\mathrm{SYM}+\mathrm{I}+\mathrm{G})$. Bayesian phylogenetic analyses were performed for each individual gene and combined gene data sets using MrBayes 3.2 [49]. Analyses for each data set consisted of two simultaneous runs for 10 million generations with four heated chains [50] and sampling occurred every 2000 generations with a $25 \%$ burn-in. Tracer v1.6 [51] was used to assess convergence of the data. A 50\% majority rule consensus tree was constructed in FigTree v1.4.2 [52] for each analysis and the percentage of samples recovered in a particular clade was assumed to represent that clade's posterior probability [53]. Average uncorrected $p$-distances were calculated for COI in PAUP ${ }^{*}$ v4.0 [54] to examine the genetic difference among taxa. Genetic lineages were determined to be potentially distinct if they differed by a minimum of $15 \%$ (uncorrected p-distance) from their closest relative. Statistical analysis was performed using the Fisher's exact test $(p<0.05)$ to assess louse parasitism from each ranch and was performed in $\mathrm{R}$ [55].

\section{Results}

\subsection{Parasitism Rates}

A total of 507 bird specimens from two sampling localities in South Texas were examined for chewing lice. The host specimens examined were taxonomically diverse, representing a total of 140 species, 36 families, and 12 orders (Table S3). Of these taxonomic categories, $32.1 \%, 58.3 \%$, and $75.0 \%$, were parasitized by ectoparasites, respectively. There were 221 birds collected from San Antonio Viejo Ranch (10.4\% were parasitized) and 286 birds collected from El Sauz (16.1\% parasitized; Table 1), although this difference in parasitism rates was not statistically significant (Fisher's exact test, $p=0.0685$ ). In total, 69 birds were parasitized by lice (13.5\%) and 63 host associations were recorded, with 29 of these associations being new (Table 2). There were 12 instances in which a host species was parasitized by more than one species of louse (Table 2). Lice from both suborders were found to be parasitizing the same host species eight times (Table 2). We note that some lice were not identified to species due to lack of reference material. Although not all specimens could be identified to species, species identity could sometimes be determined based on genetic similarity to specimens on GenBank. Additional host associations may also have been present in this study, but some louse specimens were excluded due to poor condition of the specimens or lack of reference material. 
Table 1. Species of birds that were parasitized by chewing lice in South Texas from two East Foundation ranches (San Antonio Viejo and El Sauz) during 2013-2015, where (n) is total number of host individuals per species examined.

\begin{tabular}{|c|c|c|c|}
\hline Host Order & Host Family & Host Species (n) & Locality \\
\hline Anseriformes & Anatidae & Northern Shoveler (Anas clypeata) (1) & El Sauz \\
\hline Galliformes & Odontophoridae & Northern Bobwhite (Colinus virginianus) (1) & El Sauz \\
\hline Accipitriformes & Accipitridae & Harris's Hawk (Parabuteo unicinctus) (1) & El Sauz \\
\hline Falconiformes & Falconidae & American Kestrel (Falco sparverius) (1) & San Antonio Viejo \\
\hline \multirow[t]{2}{*}{ Charadriformes } & Scolopacidae & Sanderling (Calidris alba) (1) & El Sauz \\
\hline & & Long-billed Curlew (Numenius americanus) (1) & El Sauz \\
\hline \multirow[t]{2}{*}{ Columbiformes } & Columbidae & Common Ground Dove (Columbina passerina) (1) & El Sauz \\
\hline & & Mourning Dove (Zenaida macroura) (1) & El Sauz \\
\hline \multirow{41}{*}{$\begin{array}{l}\text { Cuculiformes } \\
\text { Piciformes } \\
\text { Passeriformes }\end{array}$} & Cuculidae & Yellow-billed Cuckoo (Coccyzus americanus) (1) & San Antonio Viejo \\
\hline & Picidae & Golden-fronted Woodpecker (Melanerpes aurifrons) (1) & San Antonio Viejo \\
\hline & Alaudidae & Horned Lark (Eremophila alpestris) (1) & El Sauz \\
\hline & Cardinalidae & Northern Cardinal (Cardinalis cardinalis) (6) & El Sauz \\
\hline & & Northern Cardinal (Cardinalis cardinalis) (1) & San Antonio Viejo \\
\hline & & Painted Bunting (Passerina ciris) (1) & San Antonio Viejo \\
\hline & & Varied Bunting (Passerina versicolor) (1) & San Antonio Viejo \\
\hline & & Summer Tanager (Piranga rubra) (2) & El Sauz \\
\hline & Corvidae & Green Jay (Cyanocorax yncas) (2) & El Sauz \\
\hline & Emberizidae & Lark Sparrow (Chondestes grammacus) (1) & El Sauz \\
\hline & & Lincoln's Sparrow (Melospiza lincolnii) (1) & El Sauz \\
\hline & & Cassin's Sparrow (Pecaea cassini) (1) & San Antonio Viejo \\
\hline & Fringillidae & Lesser Goldfinch (Spinus psaltria) (1) & El Sauz \\
\hline & Iceteridae & Red-winged Blackbird (Agelaius phoeniceus) (4) & San Antonio Viejo \\
\hline & & Hooded Oriole (Icterus cucullatus) (1) & El Sauz \\
\hline & & Audubon's Oriole (Icterus graduacauda) (1) & San Antonio Viejo \\
\hline & & Bronzed Cowbird (Molothrus aeneaus) (2) & El Sauz \\
\hline & & Bronzed Cowbird (Molothrus aeneaus) (1) & San Antonio Viejo \\
\hline & & Brown-headed Cowbird (Molothrus ater) (1) & El Sauz \\
\hline & & Eastern Meadowlark (Sturnella magna) (1) & San Antonio Viejo \\
\hline & Mimidae & Northern Mockingbird (Mimus polyglottos) (6) & El Sauz \\
\hline & & Northern Mockingbird (Mimus polyglottos) (1) & San Antonio Viejo \\
\hline & & Curve-billed Thrasher (Toxostoma curvirostre) (2) & San Antonio Viejo \\
\hline & & Long-billed Thrasher (Toxostoma longirostre) (2) & El Sauz \\
\hline & & Long-billed Thrasher (Toxostoma longirostre) (1) & San Antonio Viejo \\
\hline & Hirundinidae & Tree Swallow (Tachycineta bicolor) (1) & El Sauz \\
\hline & Parulidae & Black-and-white Warbler (Mniotilta varia) (1) & El Sauz \\
\hline & & Tennessee Warbler (Oreothlypis peregrina) (1) & San Antonio Viejo \\
\hline & & Northern Waterthrush (Parkesia noeboracensis) (1) & El Sauz \\
\hline & & Louisiana Waterthrush (Parkesia motacilla) (2) & El Sauz \\
\hline & & Northern Parula (Setophaga americana) (1) & El Sauz \\
\hline & & Bay-breasted Warbler (Setophaga castanea) (1) & El Sauz \\
\hline & & Black-throated Green Warbler (Setophaga virens) (1) & El Sauz \\
\hline & & Golden-winged Warbler (Vermivora chrysoptera) (1) & El Sauz \\
\hline & Remizidae & Verdin (Auriparus flaviceps) (1) & San Antonio Viejo \\
\hline & Troglodytidae & Cactus Wren (Campylorhynchus brunneicapillus) (1) & San Antonio Viejo \\
\hline & & Carolina Wren (Thryothorus ludovicianus) (1) & El Sauz \\
\hline & Tyrannidae & Brown-crested Flycatcher (Myiarchus tyrannulus) (1) & El Sauz \\
\hline & & Vermilion Flycatcher (Pyrocephalus rubinus) (1) & San Antonio Viejo \\
\hline & & Scissor-tailed Tlycatcher (Tyrannus forficatus) (1) & El Sauz \\
\hline & Vireonidae & White-eyed Vireo (Vireo griseus) (1) & El Sauz \\
\hline
\end{tabular}


Table 2. Louse-host associations of birds sampled from South Texas during 2013-2015. Daggers ( $\dagger$ ) indicate new host associations and asterisks $\left(^{*}\right)$ indicate species with no molecular data.

\begin{tabular}{|c|c|c|c|c|}
\hline Host Order & Host Family & Host Species & Louse Suborder & Louse Species \\
\hline \multirow[t]{2}{*}{ Anseriformes } & Anatidae & Anas clypeata & Ischnocera & Anaticola crassicornis \\
\hline & & & Ischnocera & Anatoecus sp. \\
\hline Galliformes & Odontophoridae & Colinus virginianus & Ischnocera & Goniodes sp. * \\
\hline Accipitriformes & Accipitridae & Parabuteo unicinctus & Ischnocera & Degeeriella fulva + \\
\hline Falconiformes & Falconidae & Falco sparverious & Ischnocera & Degeeriella sp. \\
\hline \multirow[t]{2}{*}{ Charadriformes } & Scolopacidae & Calidris alba & Ischnocera & Lunaceps actophilus \\
\hline & & Numenius americanus & Ischnocera & $\begin{array}{l}\text { Cummingsiella } \\
\text { longirostricola }\end{array}$ \\
\hline \multirow[t]{3}{*}{ Columbiformes } & Columbidae & Columbina passerina & Ischnocera & Columbicola passerinae \\
\hline & & & Amblycera & Hohorstiella passerinae \\
\hline & & Zenaida macroura & Ischnocera & Columbicola macrourae \\
\hline Cuculiformes & Cuculidae & Coccyzus americanus & Ischnocera & Cuculoecus sp. * \\
\hline \multirow[t]{2}{*}{ Piciformes } & Picidae & Melanerpes aurifrons & Ischnocera & Penenirmus sp. * \\
\hline & & & Ischnocera & Picicola snodgrassi \\
\hline \multirow[t]{43}{*}{ Passeriformes } & Alaudidae & Eremophila alprestris & Amblycera & Menacanthus sp. †* \\
\hline & Cardinalidae & Cardinalis cardinalis & Ischnocera & Brueelia pallidula + \\
\hline & & & Amblycera & $\begin{array}{c}\text { Menacanthus } \\
\text { eurysternus }\end{array}$ \\
\hline & & & Amblycera & Myrsidea sp. + \\
\hline & & Passerina ciris & Amblycera & Myrsidea sp. †* $^{*}$ \\
\hline & & & Ischnocera & Philopterus sp. $十^{*}$ \\
\hline & & Passerina versicolor & Amblycera & Ricinus sp. \\
\hline & & Piranga rubra & Amblycera & Myrsidea sp. $\dagger^{*}$ \\
\hline & & & Ischnocera & Philopterus sp. †* $^{*}$ \\
\hline & Corvidae & Cyanocorax yncas & Amblycera & Menacanthus sp. \\
\hline & & & Amblycera & Myrsidea sp. †* $^{*}$ \\
\hline & & & Ischnocera & Philopterus sp. $十^{*}$ \\
\hline & Emberizidae & Chondestes grammacus & Amblycera & Myrsidea sp. †* $^{*}$ \\
\hline & & Melospiza lincolnii & Ischnocera & Brueelia sp. \\
\hline & & Peucaea cassinii & Ischnocera & Philopterus sp. †* \\
\hline & Fringillidae & Spinus psaltria & Ischnocera & Philopterus sp. 十* $^{*}$ \\
\hline & Hirundinidae & Tachycineta bicolor & Amblycera & Myrsidea sp. $\dagger^{*}$ \\
\hline & Iceteridae & Ageliaus phoeniceus & Ischnocera & Brueelia xanthocephali \\
\hline & & & Amblycera & Myrsidea sp. † $^{*}$ \\
\hline & & & Amblycera & Myrsidea sp. †* $^{*}$ \\
\hline & & & Ischnocera & Philopterus sp. * \\
\hline & & Icterus cucullatus & Amblycera & Menacanthus sp. + \\
\hline & & & Ischnocera & Philopterus sp. $十^{*}$ \\
\hline & & Icterus graduacauda & Ischnocera & Brueelia vulgata \\
\hline & & Molothrus aeneaus & Ischnocera & Brueelia xanthocephali \\
\hline & & Molothrus ater & Ischnocera & Brueelia xanthocephali \\
\hline & & & Amblycera & Myrsidea sp. \\
\hline & & Sturnella magna & Ischnocera & Brueelia picturata \\
\hline & Mimidae & Mimus polyglottos & Ischnocera & Brueelia brunneinucha \\
\hline & & & Amblycera & Myrsidea sp. †* $^{*}$ \\
\hline & & & Ischnocera & Philopterus sp. * \\
\hline & & Toxostoma curvirostre & Ischnocera & Brueelia dorsale \\
\hline & & Toxostoma longirostre & Ischnocera & Brueelia brunneinucha $†$ \\
\hline & & & Ischnocera & Brueelia dorsale + \\
\hline & & & Ischnocera & Philopterus sp. $\dagger^{*}$ \\
\hline & & & Ischnocera & Brueelia sp. $+^{*}$ \\
\hline & Parulidae & Mniotilta varia & Ischnocera & Philopterus sp. $十^{*}$ \\
\hline & & Oreothlypis peregrina & Amblycera & Ricinus sp. * \\
\hline & & Parkesia noveboracensis & Amblycera & Ricinus sp. * \\
\hline & & Parkesia motacilla & Amblycera & Myrsidea sp. * \\
\hline & & Setophaga americana & Amblycera & Menacanthus sp. +* \\
\hline & & Setophaga virens & Amblycera & Myrsidea sp. $†$ \\
\hline & & Vermivora chrysoptera & Amblycera & Ricinus sp. * \\
\hline
\end{tabular}


Table 2. Cont.

\begin{tabular}{|c|c|c|c|c|}
\hline Host Order & Host Family & Host Species & Louse Suborder & Louse Species \\
\hline & Remizidae & Auriparus flaviceps & Ischnocera & Brueelia sp. * \\
\hline & Troglodytidae & $\begin{array}{c}\text { Campylorhynchus } \\
\text { brunneicapillus }\end{array}$ & Ischnocera & Brueelia dorsale + \\
\hline & & Thryothorus ludovicianus & Amblycera & Myrsidea sp. \\
\hline & Tyrannidae & Myiarchus tyrannulus & Amblycera & Menacanthus sp. †* $^{*}$ \\
\hline & & Pyrocephalus rubinus & Amblycera & Ricinus sp. \\
\hline & & Tyrannus forficatus & Ischnocera & Picicola sp. * \\
\hline & Vireonidae & Vireo griseus & Ischnocera & Brueelia dorsale + \\
\hline
\end{tabular}

\subsection{COI Analyses}

There were a total of 148 chewing louse specimens included in the COI phylogenetic analysis: 81 specimens ( 35 Amblycera and 46 Ischnocera) from South Texas and 67 (20 Amblycera, 45 Ischnocera, and two Anoplura) from GenBank (Figures 2 and 3). There were high average pairwise sequence divergences (uncorrected $p$-distances) within each suborder: across amblyceran taxa, the average uncorrected $p$-distance was $23.3 \%$ with a range of $0-35.7 \%$; across ischnoceran taxa, the average uncorrected $p$-distance was $26.1 \%$ with a range of $0-37.3 \%$. From this study, there were 21 distinct genetic lineages (seven from Amblycera and 14 from Ischnocera), each of which was approximately $15 \%$ genetically divergent (uncorrected $p$-distance) from their closest relative (Figures 2 and 3).

Phylogenetic analysis of the amblyceran taxa resulted in three clades with strong Bayesian posterior probability (PP) support; each clade circumscribes a major louse genus (Figure 2). Myrsidea had the strongest support (PP =1), and the Ricinus and Menacanthus clades were strongly supported as well $(\mathrm{PP}=0.99)$. Support for relationships within each clade varied. In Menacanthus and Ricinus, more relationships were strongly supported when compared to Myrsidea. Within Myrsidea, most relationships were poorly supported, effectively resulting in a major polytomy within this genus. The analysis also included the amblyceran genus Hohorstiella, which was placed as sister to Menacanthus; however, this relationship was poorly supported $(\mathrm{PP}=0.73)$.

Analysis of the ischnoceran suborder revealed several well-supported clades (Figure 3). The louse genera Columbicola, Anaticola, and Anatoecus were recovered together in a clade, with posterior support of 0.94 . The Degeeriella complex, comprising the genera Degeeriella, Picicola, Trogoninirmus, and Contingacola, was strongly supported ( $\mathrm{PP}=1)$, although intergeneric relationships were not strongly supported and Picicola was not recovered as monophyletic. Members of the louse genera Cummingsiella, Lunaceps, Penenirmus (not recovered as monophyletic), Cuculoecus, and Goniodes comprised a poorly supported clade, sister to Philopterus $(\mathrm{PP}=0.99)$. While Philopterus was strongly supported $(\mathrm{PP}=0.99)$, the relationships within the genus were not. The same is true for the largest ischnoceran clade that comprised of members of the hyper-diverse genus Brueelia. This clade was strongly supported $(\mathrm{PP}=1)$; however, support for relationships within the clade was lacking.

\subsection{S, EF-1 $\alpha$, and Combined Analyses}

A total of 49 chewing louse specimens were included in the $18 \mathrm{~S}$ phylogenetic analyses: 44 specimens from South Texas (16 Amblycera and 28 Ischnocera) and five from GenBank (one Amblycera, two Ischnocera, and two Anoplura; Figure S1). There were 55 specimens included in the EF- $1 \alpha$ analysis, 36 lice from South Texas (16 Amblycera, 20 Ischnocera) and 19 from GenBank (six Amblycera, nine Ischnocera and two Anoplura; Figure S2). The large clades recovered in the COI analysis were recovered in both $18 \mathrm{~S}$ and EF- $1 \alpha$. A monophyletic Ischnocera was not supported with analysis of EF-1 $\alpha$ (Figure S2). Each gene analysis revealed slightly different relationships within those large clades, although they were poorly supported. 


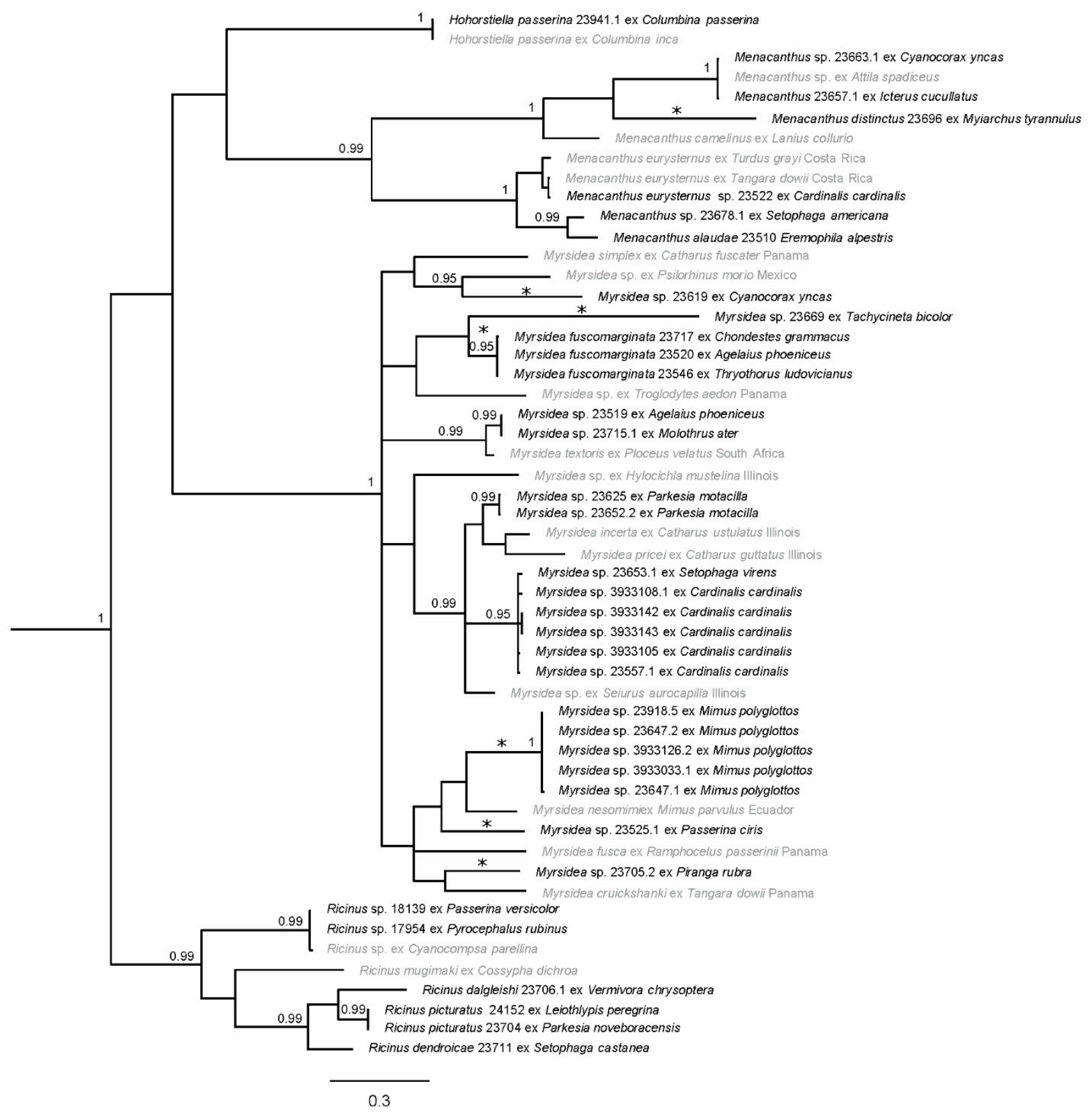

Figure 2. Bayesian phylogram of amblyceran taxa from south Texas. Posterior probabilities $\geq 0.95$ are shown and sequences in gray are from GenBank. Distinct genetic lineages are denoted with asterisks $\left(^{*}\right)$; one of these lineages (Menacanthus distinctus) represents a morphologically described taxon. Taxon labels for newly sequenced specimens include the louse species (if identified), unique identifier (generally matching the host voucher number), and host species. Taxon labels for GenBank specimens include louse species (if known), host species, and sampling location (if known). Outgroup taxa have been pruned. 


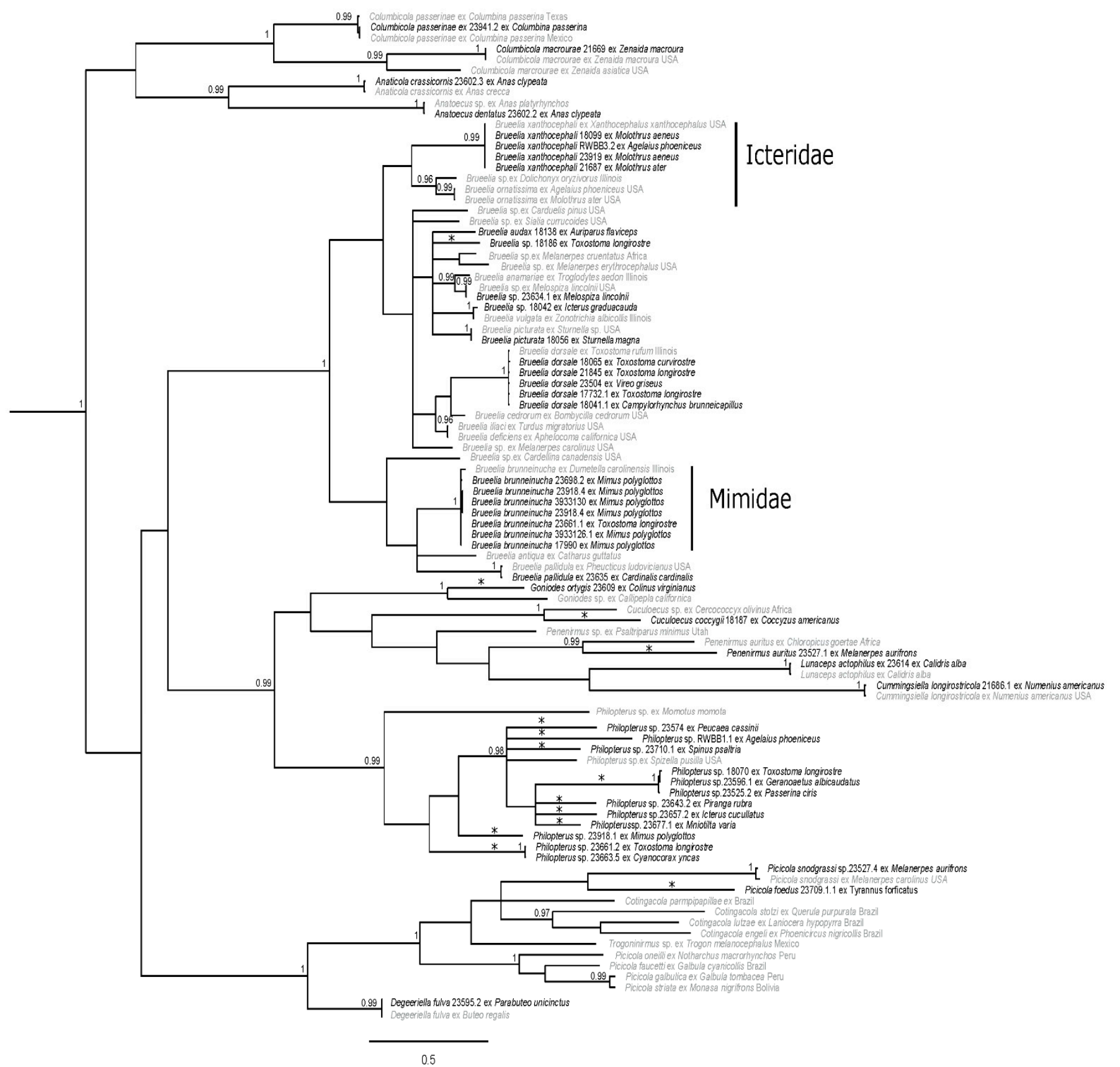

Figure 3. Bayesian phylogram of ischnoceran taxa from south Texas. Posterior probabilities $\geq 0.95$ are shown and sequences in gray are from GenBank. Distinct genetic lineages are denoted with asterisks ${ }^{*}$ ); two of these lineages (Goniodes ortygis, Penenirmus auritus) represent morphologically described taxa. The host families Icteridae and Mimidae are shown to the right of louse clades exclusively shown here to parasitize them. Taxon labels for newly sequenced specimens include the louse species (if identified), unique identifier (generally matching the host voucher number), and host species. Taxon labels for GenBank specimens include louse species (if known), host species, and sampling location (if known). Outgroup taxa have been pruned.

When the two nuclear genes, $18 \mathrm{~S}$ and EF-1 $\alpha$ (52 samples from South Texas and 16 from GenBank), were analyzed together, the results gave high support for the suborders and many of the genera and intergeneric relationships (Figure S3). The analysis of COI+18S (45 samples from South Texas and three from GenBank) provided resolved and well-supported relationships (Figure S4), more so than the analysis of the combined nuclear genes (Figure S3). The relationships seen in the tree resulting from the COI+EF- $1 \alpha$ analysis (37 samples from South Texas and 16 from GenBank) also received high support, although Ischnocera 
was again not supported as monophyletic (Figure S5). When all three genes were combined into one analysis (50 samples from South Texas and 18 from GenBank), suborder, genera, and intergeneric relationships were resolved and well-supported, more so than any of the analyses of individual or combined gene data sets (Figure 4). Notably, this three-gene tree topology is very similar to that seen in the COI-only trees (Figures 2 and 3), although relationships were better resolved and supported across the tree (Figure 4).

\section{Ischnocera}

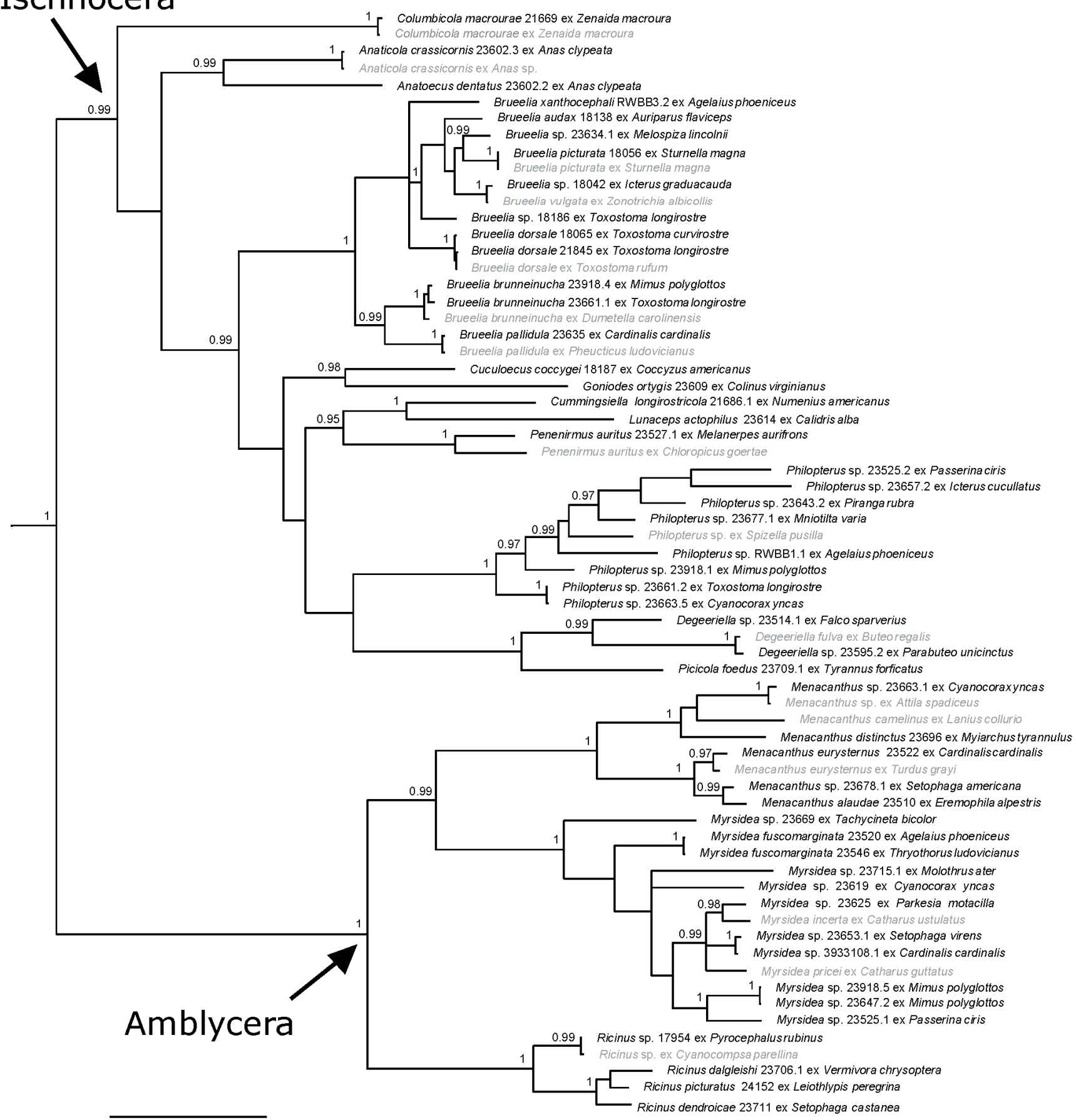

Figure 4. Bayesian phylogram of combined mitochondrial (COI gene) and nuclear genes (18S and EF-1 $\alpha$ ). Posterior probabilities $\geq 0.95$ are shown and sequences in gray are from GenBank. Taxon labels for newly sequenced specimens include the louse species (if identified), unique identifier (generally matching the host voucher number), and host species. Taxon labels for GenBank specimens include louse species (if known) and host species. Outgroup taxa have been pruned. 


\section{Discussion}

With respect to parasitism rates, the bird species examined for chewing lice in this study represent a taxonomically diverse subset of species occurring in South Texas. Overall, we recovered a parasitism rate of $13.5 \%$, despite having sampled across seasons. Indeed, our recovered parasitism rate would have been even lower, had we not sampled migratory birds in spring (e.g., Parulidae taxa). Previous studies that have assessed broad assemblages of host species for lice have found somewhat similar parasitism rates of 8.3\% (Benin [56]), 19\% (Democratic Republic of the Congo [45]), 20\% (Brazil [57]), and 22\% (South Africa [58]). The findings of this study were not consistent with the extraordinarily high parasitism rate of $60 \%$ or more observed from Central America, South America, and Europe [19,59-61]. Some of these studies reflect parasitism rates from a single season sampling event (e.g., [58]), while others reflect parasitism rates from across multiple seasons (e.g., [57]).

While chewing louse prevalence may vary geographically or by sampling method [62], low parasitism rates could be attributable to abiotic factors, such as climate. There is evidence that shows that aridity could be a driving force in reducing louse parasitism rates among birds inhabiting arid environments [11,15]. The area of South Texas where sampling occurred is a semi-arid habitat that can be heavily influenced by long periods of drought [63]. At the time of our study, South Texas was at the end of a three-year drought event, where the average precipitation during 2010-2012 was approximately $48.0 \mathrm{~cm}$ per year. This average is considerably lower than the average precipitation per year of $64.3 \mathrm{~cm}$ recorded from South Texas over a 30-year period (1981-2010 via [64]). Interestingly, when individual ranches were compared (San Antonio Viejo, which is arid and inland versus El Sauz, which is humid and coastal), there was no statistically significant difference in louse parasitism rates, which were $10.4 \%$ and $16.1 \%$, respectively. It is therefore possible that during the time of this study El Sauz was not significantly more humid than San Antonio Viejo, possibly due to the drought (and despite different 30-year rainfall averages; see Methods). Notably, the intensity (or abundance) of lice on each host was higher on birds sampled from El Sauz than they were at San Antonio Viejo. For example, rather than finding one to three lice per host from San Antonio Viejo birds, birds from El Sauz (coastal climate, higher average rainfall) were generally parasitized by five or more lice per host individual, and in some instances as many as 30 lice on a single host. Therefore, it is a possibility that humidity does not have a substantial influence on louse prevalence and instead has more of an effect on intensity of individual host parasitism. A similar phenomenon has been described in previous studies in which host species at humid locations exhibit higher intensity of louse parasitism than arid locations $[15,65]$.

With respect to phylogeny, within the amblyceran tree we recovered seven genetically distinct lineages, one of which we were able to morphologically identify (Figure 3). We discuss relationships among chewing louse lineages based primarily on the mitochondrial COI data set. We note for the most part that the nuclear data added additional support to the phylogeny. The only discrepancy was that the nuclear EF- $1 \alpha$ gene did not support a monophyletic Ischnocera. This has been documented in the literature several times (e.g., $[41,45,56,66])$, and is generally believed to be the result of poor taxonomic sampling. However, the fact that the slower evolving $18 \mathrm{~S}$ did support a monophyletic Ischnocera implies that faster evolving EF- $1 \alpha$ may not be the best nuclear marker to use to reconstruct relationships at higher taxonomic levels [66].

Within the amblyceran tree (Figure 2), Menacanthus lice that parasitized Green Jay (Cyanocorax yncas) and Hooded Oriole (Icterus cucullatus) were almost identical genetically (average of $0.2 \%$ uncorrected $p$-distance) to the GenBank Menacanthus sp. from Brightrumped Attila (Attila spadiceus); these likely represent the same species. It is unclear as to how these three behaviorally disparate taxa share this louse taxon; one possibility is transmission to wintering Hooded Orioles from tropical resident Bright-rumped Attila's, with subsequent transmission to Green Jays (which are sedentary) from breeding Hooded Orioles in Texas. Regardless, this Menacanthus subclade genetically differed on average $17.0 \%$ from the Menacanthus sp. parasitizing the Brown-crested Flycatcher (Myiarchus 
tyrannulus). Based on the amount of genetic divergence and a novel host association (Table 2), this Myiarchus flycatcher louse is likely a new species. A louse specimen we collected from a Northern Cardinal (Cardinalis cardinalis) was genetically similar to the louse parasitizing a Spangle-cheeked Tanager (Tangara dowii; $1.4 \%$ uncorrected $p$-distance). This could reflect the louse parasitizing the cardinal as being the same species (Menachanthus eurysternus) and it may have a large geographic range from South Texas to Costa Rica (and possibly much larger than that). The lice from Northern Parula (Setophaga americana) and Horned Lark (Eremophila alpestris) are on average 11.2\% divergent from Menacanthus eurysternus (and 6\% divergent from each other) and both represent novel host associations. The Menacanthus eurysternus complex is highly contentious; some believe it is widely distributed and parasitizes numerous host families and species [2,38], while others believe the complex contains subspecies or several similar species [67]. As such, its taxonomic status is uncertain [67]. Additionally, although an average of $11.2 \%$ genetic divergence is high, it may fall within the range of differentiation for a widespread species [9]. Thus, it is unclear if the Menacanthus lice parasitizing Setophaga americana and Eremophla alpetris represent a unique genetic lineage (even though both are new host associations) or normal diversity within a widespread louse lineage.

The genus Myrsidea is the most speciose genus in Phthiraptera, with 350 described species and new species frequently being described (e.g., [68-75]). In our study, there are six distinct genetic lineages within Myrsidea (Figure 2). High divergence was recorded in the louse collected from the Green Jay (Cyanocorax yncas) compared to its closest genetic relative (19.3\%), a louse which parasitizes the Brown Jay (Psilorhinus morio) from Mexico. Notably, the Brown Jay has a similar distribution and belongs to the same family (Corvidae) as the Green Jay. Although we were unable to amplify any nuclear genes for the Myrsidea louse parasitizing the Green Jay, its COI sequence is genetically distinct and given this is a new host association (Table 2), this louse is likely new to science. A similarly high average divergence $(18.7 \%)$ was recorded from the lice parasitizing the Tree Swallow (Tachycineta bicolor) as compared to the louse lineage parasitizing Carolina Wren (Thryothorus ludovicianus), Red-winged Blackbird (Agelaius phoeniceus), and Lark Sparrow (Chondestes grammacus). The Myrsidea found parasitizing these host taxa represent novel host associations, excluding the Carolina Wren (Table 2), and potentially new species.

Chewing lice found parasitizing the Louisiana waterthrush (Parkesia motacilla) have been previously recorded (identified as Myrsidea paleno [21]), but our study may be the first to obtain genetic data from this louse species (we did not have morphological material to definitively confirm this). There is a potential distinct Myrsidea lineage parasitizing Northern Cardinals (Cardinalis cardinalis) and the Black-throated Green Warbler (Setophaga virens), which represent two previously unrecorded host associations and were $12.6 \%$ divergent from other Myrsidea in this subclade. The lice collected from Northern Mockingbirds (Mimus polyglottos) are, on average, $14.4 \%$ genetically different from the closest GenBank sequence (Myrsidea nesomimi) collected from the Galapagos Mockingbird (Mimus parvulus). Although this genetic divergence is not quite as high as our 15\% limit described above, it is still substantial and may reflect a new species especially when considering that little is known about Northern mockingbirds being parasitized by Myrsidea lice (Table 2). Notably, a previous phylogenetic study concluded that the Galapagos Mockingbird's closest relative is a member of the North American mockingbird genus, Mimus [76]. This analysis then led to the merging of the endemic Galapagos Mockingbird genus Nesomimus into Mimus. It is conceivable that when North American mockingbird species colonized the Galapagos Islands, they brought their parasites along with them, which subsequently diverged as their hosts diverged. This could potentially explain why the Myrsidea lice collected from Northern Mockingbirds in this study formed a sister clade to the lice from the Galapagos Mockingbird. The genus Mimus and the Myrsidea lice parasitizing them could therefore be a good study system for future studies of host-parasite coevolution.

Moreover, within Myrsidea, a Painted Bunting (Passerina ciris) was host to a distinct chewing louse lineage roughly $15.4 \%$ divergent from the sister clade of mockingbirds. 
Given that this association is new to science (Table 2), it is likely that this Myrsidea lineage represents a new species. Additionally, the Myrsidea sp. parasitizing the Summer Tanager (Piranga rubra) is a novel host association (Table 2 ) and is $14.5 \%$ genetically different than its sister taxa (Myrsidea cruickshanki) that was found parasitizing Spangle-cheeked Tanager (Tangara dowii) and possibly represents a louse species new to science. Interestingly, the genus Piranga belonged to the same family as Tangara, Thraupidae, until 2003 when it was reclassified based on data showing that Piranga is genetically part of Cardinalidae [77]. A driving force for this split may be associated with geographic structuring as true thraupines includes species with a Neotropical distribution $[77,78]$. Perhaps the geographic structuring we see within the distantly related host species is being mirrored by the lice that parasitize them. Finally, within Myrsidea there is an interesting relationship with the louse Myrsidea textoris. The louse specimen of this species from GenBank was collected in South Africa from a Southern Masked Weaver (Ploceus velatus) and is known from several other South African host species including Lesser Masked Weaver (Ploceus intermedius) and Spectacled Weaver (Ploceus ocularis) [58]. In our study two separate hosts, Red-winged Blackbird and Brown-headed Cowbird (Molothrus ater), were likely parasitized by this louse species based on an average $4.9 \%$ genetic divergence (uncorrected $p$-distance). Another Ploceus host species, African Village Weaver (Ploceus cucullatus) was introduced to Hispanolia [79] and is a known host of Myrsidea textoris. These established Hispanolia populations of Village Weavers have been recorded flocking with Shiny Cowbirds (Molothrus bonariensis) in the Dominican Republic [80]. Due to proximity, transmission from Village Weavers to Shiny Cowbirds could have occurred. The Shiny Cowbird has distributional overlap with both the Red-winged Blackbird and Brown-headed Cowbird in southern Florida and parts of Central America. These past introductions and distribution overlaps of host species could possibly explain the intercontinental distribution for Myrsidea textoris.

Ricinus lice formed several sub-clades (Figure 2). One of these was Ricinus parasitizing the Golden-winged Warbler (Vermivora chrysoptera), Tennessee Warbler (Oreothlypis peregrina), Northern Waterthrush (Parkesia noveboracensis), and Bay-breasted Warbler (Setophaga castanea) which formed one sub-clade, are on average $12.2 \%$ genetically different from each other, and this sub-clade is sister to Ricinus mugimaki parasitizing a host from South Africa (Chorister Robin-chat, Cossypha dichroa). When looking at known louse-host associations, different species of Ricinus are known to parasitize each of the host species within this clade. There are known host associations of Ricinus picturatus parasitizing members from the genus Vermivora [81] such as the Golden-winged Warbler and the former Vermivora member (now Leiothlypis), Tennessee Warbler. There are records of Ricinus seiuri parasitizing the Northern Waterthrush and the Bay-breasted Warbler has a known association with Ricinus dendroicae. Unfortunately, there are no molecular data available for these particular Ricinus species. Given this lack of genetic information coupled with the inability to morphological identify these lice to species, we can only discern that there are potentially three louse species in this clade based on genetic divergence and host associations. A last subclade reflects Ricinus sp. parasitizing a Varied Bunting (Passerina versicolor) and a Vermilion Flycatcher (Pyrocephalus rubinus), which are genetically almost identical to a Ricinus sp. parasitizing (Cyanocompsa parellina).

Finally, we found in the amblyceran tree a single species of Hohorstiella (passerinae) parasitizing a Common Ground Dove (Columbina passerinae); this species is known to parasitize other dove species to include Inca Dove (Columbina inca; Figure 2).

Within the ischnoceran tree, we recovered 14 genetically distinct lineages, several of which we were able to morphologically identify (Figure 3). This is not particularly surprising as numerous ischnoceran species and host associations are being discovered and described globally (e.g., [58,82-88]). However, these new descriptions often come from areas that are traditionally understudied in terms of host and louse diversity. The fact that there are 14 distinct lineages from South Texas is somewhat surprising; nine of these come from one genus and four are known louse-host associations that lack genetic reference material. 
All Brueelia in this study were genetically identical or nearly identical to sequences obtained from GenBank, with the exception of two specimens (Figure 3). The two exceptions were collected from a Verdin (Auriparus flaviceps), which has a known association with Brueelia audax and Bell's Vireo (Vireo bellii), and they are an average of $13.0 \%$ and $14.1 \%$ different from other Brueelia in their subclade, respectively. These are potential unique genetic lineages coupled with novel host associations (Table 2), revealing a strong possibility of new species within Brueelia. There have been numerous studies over the past few years that have focused efforts on collecting Brueelia sp. and using molecular analysis to resolve the Brueelia complex [89]. Recently Bush et al. [90] recognized this group as being paraphyletic and Gustafsson and Bush [91] proposed a revised classification of the complex based on morphological data and excluding host relationships. This genus is one of the largest groups within Ischnocera, originally containing over 260 described species of which roughly $90 \%$ are host specific [92] and further investigation increased this number to 426 species [91]. In fact, our phylogeny reflects specificity for some species to host family (Figure 3). For example, one Brueelia lineage was found to only parasitize species located in the bird family Mimidae (Figure 3). This lineage likely represents individuals of Bruellia brunneinucha based on minimal genetic divergence from the GenBank specimen and because this louse species targets other mimids as well, with described associations with Tropical Mockingbird (Mimus gilvus), Blue-and-white Mockingbird (Melanotis hypoleucus), and Bahama Mockingbird (Mimus gundlachii [93]). Another example of host family specificity applies to Bruellia xanthocephali and Bruellia ornatissima, which collectively form a clade that appears to only parasitize members of family Icteridae (Figure 3). However, there is also a group of hosts that appears to be parasitized by a non-host specific louse, Bruellia dorsale; this louse is recovered as parasitizing four different host species from three different families (Figure 3). Interestingly, the host species that form that clade frequently inhabit thorn-scrub and dense vegetation. This suggests that Bruellia dorsale may represent an opportunistic parasite within that particular habitat. Our results for Brueelia support the conclusions of Johnson et al. [92], who regarded Brueelia as having members that were both host specific and host generalists.

The Penenirmus collected from the Golden-fronted Woodpecker (Melanerpes aurifrons) was highly supported as sister to a louse collected from another Picidae species, the African Gray Woodpecker (Chloropicus goertae) although these two louse species were highly divergent $(21.3 \%)$. Sister to the clade of Penenirmus woodpecker lice are two other louse genera, Lunaceps and Cummingsiella, to the exclusion of the Penenirmus parasitizing the Bushtit (Psaltriparus minimus). This renders the genus Penenirmus polyphyletic, where different lineages parasitize Piciformes and Passeriformes hosts. These results, although representing limited sampling, support previous literature finding a lack of monophyly for Penenirmus $[45,58,94]$ and the necessity for taxonomic revision of this louse genus.

While the genus Philopterus is well supported, it is effectively a large polytomy with high amounts of divergence (average uncorrected $p$-distance 20.7\%) among lineages (Figure 3). As such, it is difficult to determine relationships within this genus. This difficulty is exacerbated by the general lack of genetic references on GenBank until recently [84]. Unfortunately, many of the samples in this clade were nymphs, thus it was difficult for us to identify any of these samples to species. Of the nine recorded distinct lineages within this genus (22.3\% average $p$-distance), seven are associated with novel host associations (Figure 3, Table 2). Most of the records detailing Philopterus and their host associations in North America are many decades old (e.g., [95,96]) and are based solely on morphology. In general, there is little recent information providing molecular data or new host associations about the genus apart from Price et al. [1], Mey [97], Bush et al. [11], and Najer et al. [84]. Clearly, additional molecular and morphological studies focused on Philopterus are needed.

A well supported clade that is referred to as the Degeeriella complex by Clay [98] was recovered within the ischnoceran phylogeny (Figure 3). This clade, which comprises several genera including Degeeriella, Picicola, Trogoninirmus, and Cotingacola, is often defined as being strongly supported based on morphology and molecular data, although 
many genera within this group have been shown to be paraphyletic $[99,100]$. Specifically, the genus Picicola has been shown to be paraphyletic in many studies (e.g., [28,45,100]), including our own (Figure 3). Looking into the complex a bit further, we have a distinct lineage parasitizing the Scissor-tailed flycatcher (Tyrannus forficatus) that is an average of $22.4 \%$ divergent from the clade containing the Picicola lice parasitizing Melanerpes species. While Picicola foedus is known to parasitize the Scissor-tailed flycatcher, molecular data demonstrating this association are not available. Therefore, we provide new molecular information about this host association. If the louse from this study is found to be morphologically different from the louse identified in the original louse-host association, this could potentially represent a new species.

Supplementary Materials: The following are available online at https://www.mdpi.com/article/ 10.3390/d13090430/s1. Figure S1: Bayesian phylogeny of nuclear gene (18S). Figure S2: Bayesian phylogeny of nuclear gene (EF-1 $\alpha$ ). Figure S3: Bayesian phylogeny of combined nuclear genes. Figure S4: Bayesian phylogeny of combined mitochondrial (COI gene) and nuclear gene (18S). Figure S5: Bayesian phylogeny of combined mitochondrial (COI gene) and nuclear gene (EF-1 $\alpha$ ). Table S1: Louse sequences obtained from GenBank. Table S2: Louse specimens used in analysis from South Texas. Table S3: Avian species sampled for lice in south Texas.

Author Contributions: Conceptualization, J.P.P. and G.V.; methodology, J.P.P., J.E.L., T.A.C. (Therese A. Catanach) and G.V.; formal analysis, J.P.P., J.E.L., T.A.C. (Therese A. Catanach), G.V.; investigation, J.P.P., J.E.L., T.A.C. (Therese A. Catanach), G.V.; resources, J.E.L., T.A.C. (Tyler A. Campbell), G.V.; data curation, J.E.L. and G.V.; writing—original draft preparation, J.P.P.; writing—review and editing, J.P.P., J.E.L., T.A.C. (Tyler A. Campbell), T.A.C. (Therese A. Catanach), G.V.; funding acquisition, J.E.L., T.A.C. (Tyler A. Campbell), G.V. All authors have read and agreed to the published version of the manuscript.

Funding: This research was funded by the East Foundation.

Institutional Review Board Statement: This study was approved by the Texas A\&M University Institutional Animal Care and Use Committee (AUP 2012-6 and 2015-0020).

Data Availability Statement: Sequences are available on GenBank (see Supplementary Table S2).

Acknowledgments: We thank the East Foundation for funding this study and allowing us to conduct research on their ranches. We also thank Adrian Castellanos for his help creating Figure 1 and Jerry Huntley for his help during analysis. This is publication number 019 of the East Foundation, and publication number 1651 of the Biodiversity Research and Teaching Collections at Texas A\&M University.

Conflicts of Interest: The authors declare no conflict of interest.

\section{References}

1. Johnson, K.P.; Clayton, D.H. The biology, ecology, and evolution of chewing lice. In The Chewing Lice: World Checklist and Biological Overview; Special Publication 24; Price, R.D., Hellenthal, R.A., Palma, R.L., Johnson, K.P., Clayton, D.H., Eds.; Illinois Natural History Survey: Champaign, IL, USA, 2003; pp. 449-476.

2. Johnson, K.P.; Clayton, D.H. The Chewing Lice: World Checklist and Biological Overview; Special Publication 24; Price, R.D., Hellenthal, R.A., Palma, R.L., Johnson, K.P., Clayton, D.H., Eds.; IllinoisNatural History Survey: Champaign, IL, USA, 2003 ; p. 501.

3. Waterhouse, D.F. Studies on the digestion of wool by insects. IX. Some features of digestion in chewing lice (Mallophaga) from bird and mammalian hosts. Aust. J. Biol. Sci. 1953, 6, 257-275. [CrossRef]

4. Johnson, K.P.; Shreve, S.M.; Smith, V.S. Repeated adaptive divergence of microhabitat specialization in avian feather lice. BMC Biol. 2012, 10, 52. [CrossRef]

5. Marshall, A.G. The Ecology of Ectoparasitic Insects; Academic Press: London, UK, 1981; p. 459.

6. Keirans, J.E. A Review of the Phoretic Relationship between Mallophaga (Phthiraptera: Insecta) and Hippoboscidae (Diptera: Insecta). J. Med. Entomol. 1975, 12, 71-76. [CrossRef]

7. Bartlow, A.W.; Villa, S.M.; Thompson, M.W.; Bush, S.E. Walk or ride? Phoretic behaviour of amblyceran and ischnoceran lice. Int. J. Parasitol. 2016, 46, 221-227. [CrossRef]

8. Harbison, C.W.; Jacobsen, M.V.; Clayton, D.H. A hitchhiker's guide to parasite transmission: The phoretic behaviour of feather lice. Int. J. Parasitol. 2009, 39, 569-575. [CrossRef] [PubMed]

9. Malenke, J.R.; Johnson, K.P.; Clayton, D.H. Host specialization differentiates cryptic species of feather-feeding lice. Evolution 2009, 63, 1428-1438. [CrossRef] [PubMed] 
10. Lane, R.S.; Kucera, T.F.; Barrett, R.H.; Mun, J.; Wu, C.; Smith, V.S. Wild turkey (Meleagris gallopavo) as a host of Ixodid ticks, lice, and Lyme disease Spirochetes (Borrelia burgdoferi sensu lato) in California state parks. J. Wildlife Dis. 2006, 42, 759-771. [CrossRef]

11. Bush, S.E.; Harbison, C.W.; Slager, D.L.; Peterson, A.T.; Price, R.D. Geographic variation in the community structure of lice on Western scrub-jays. Amer. Soc. Parasitol. 2009, 95, 10-13. [CrossRef]

12. Bueter, C.; Weckstein, J.; Johnson, K.P.; Bates, J.M.; Gordon, C.E. Comparative phylogenetic histories of two louse genera found on Catharus thrushes and other birds. J. Parasitol. 2009, 95, 295-307. [CrossRef] [PubMed]

13. Galloway, T.D.; Palma, R.L. Serendipity with chewing lice (Phthiraptera: Menoponidae, Philopteridae) infesting rock pigeons and mourning doves (Aves: Columbiformes: Columbidae) in Manitoba, with new records for North America and Canada. Entomol. Soc. Can. 2008, 140, 208-218. [CrossRef]

14. Johnson, K.P.; Williams, B.L.; Drown, D.M.; Adams, R.J.; Clayton, D.H. The population genetics of host specificity: Genetic differentiation in dove lice (Insecta: Phthiraptera). Mol. Ecol. 2002, 11, 25-38. [CrossRef]

15. Moyer, B.R.; Drown, D.M.; Clayton, D.H. Low humidity reduces ectoparasite pressure: Implications for host life history evolution. Oikos 2002, 97, 223-228. [CrossRef]

16. Bush, S.E.; Clayton, D.H. The role of body size in host specificity: Reciprocal transfer experiments with feather lice. Evolution 2006, 60, 2158-2167. [CrossRef]

17. Jahrsdoerfer, S.E.; Leslie, D.M.J. Tamaulipan brushland of the lower Rio Grande Valley of South Texas: Description, human impacts, and management options. U. S. Fish Wildl. Serv. Biol. Rep. 1988, 88, 63.

18. Clayton, D.H.; Johnson, K.P. Linking Coevolutionary History to Ecological Process: Doves and Lice. Evolution 2003, 57, $2335-2341$. [CrossRef] [PubMed]

19. Lindell, C.A.; Gavin, T.A.; Price, R.D.; Sanders, A.L. Chewing Louse Distributions on two Neotropical Thrush species. Comp. Parasitol. 2002, 69, 212-217. [CrossRef]

20. Sychra, O.; Najer, T.; Kounek, F.; Capek, M.; Literak, I. Chewing lice (Phthiraptera) on manakins (Passeriformes: Pipridae) from Costa Rica, with description of a new species of the genus Tyranniphilopterus (Phthiraptera: Philopteridae). Parasitol. Res. 2010, 106, 925-931. [CrossRef]

21. Kounek, F.; Sychra, O.; Capek, M.; Lipkova, A.; Literak, I. Chewing lice of the genus Myrsidea (Phthiraptera: Menoponidae) from the Cardinalidae, Emberizidae, Fringillidae and Thraupidae (Aves: Passeriformes) from Costa Rica, with descriptions of four new species. Zootaxa 2011, 3137, 1-16. [CrossRef]

22. Price, R.D.; Johnson, K.P. Five new species of Myrsidea Waterston (Phthiraptera: Menoponidae) from tanagers (Passeriformes: Thraupidae) in Panama. Zootaxa 2009, 2200, 61-68. [CrossRef]

23. Prism Climate Group. Available online: https:/ / prism.oregonstate.edu/ (accessed on 10 September 2015).

24. Clayton, D.H.; Gregory, N.G.; Price, R.D. Comparative ecology of Neotropical bird lice (Insecta: Phthiraptera). J. Anim. Ecol. 1992, 61, 781-795. [CrossRef]

25. Clayton, D.H.; Drown, D.M. Critical evaluation of five methods for quantifying chewing lice (Insecta: Phthiraptera). J. Parasitol. 2001, 87, 1291-1300. [CrossRef]

26. Walther, B.A.; Clayton, D.H. Dust-Ruffling: A simple method for quantifying ectoparasite loads of live birds. J. Field Ornithol. 1997, 68, 509-518.

27. Palma, R.L. Slide-mounting of lice: A detailed description of the Canada balsam technique. N. Z. Entomol. 1978, 6, 432-436. [CrossRef]

28. Catanach, T.A.; Johnson, K.P. Independent origins of the feather lice (Insecta: Degeeriella) of raptors. Biol. J. Linn. Soc. 2015, 114, 837-847. [CrossRef]

29. Carriker, M.A., Jr. Report on a collection of Mallophaga, largely Mexican (Part II). Fla. Entomol. 1956, 39, 19-43. [CrossRef]

30. Clay, T. Contributions towards a revision of Myrsidea Waterston. I. (Menoponidae: Mallophaga). Bull. Br. Mus. Nat. Hist. Entomol. 1966, 17, 327-395. [CrossRef]

31. Clay, T. Contributions towards a revision of Myrsidea Waterston. III. (Menoponidae: Mallophaga). Bull. Br. Mus. Nat. Hist. Entomol. 1968, 21, 203-243.

32. Dalgleish, R.C. The Penenirmus (Mallophaga: Ischnocera) of the Picidae (Aves: Piciformes). J. N. Y. Entomol. Soc. 1972, 80, 83-104.

33. Emerson, K. A New Mallophaga from a Ruffed Grouse. J. Kansas Entomol. Soc. 1948, 21, 92-95.

34. Emerson, K. New species of Goniodes. J. Kansas Entomol. Soc. 1950, 23, 120-126.

35. Grossi, A.A.; Sharanowski, B.A.; Galloway, T.D. Anatoecus species (Phthiraptera: Philopteridae) from Anseriformes in North America and taxonomic status of Anatoecus dentatus and Anatoecus icterodes. Can. Entomol. 2014, 146, 598-608. [CrossRef]

36. Kellogg, V.L. New Mallophaga, III. Mallophaga from birds of Panama, Baja California, and Alaska. Occ. Papers Cal. Acad. Sci. 1899, 6, 3-52.

37. Osborn, H. Insects affecting domestic animals: An account of the species of importance in North America, with mention of related forms occurring on other animals. Bull. U. S. Dep. Agric. Divisi. Entomol. 1896, 5, 1-302.

38. Price, R.D. The Menacanthus eurysternus Complex (Mallophaga: Menoponidae) of the Passeriformes and Piciformes (Aves). Ann. Entomol. Soc. Amer. 1975, 68, 617-622. [CrossRef]

39. Price, R.D. The Menacanthus (Mallophaga: Menoponidae) of the Passeriformes (Aves). J. Med. Entomol. 1977, 14, 207-220. [CrossRef]

40. Williams, N.S. The Picicola (Mallophaga: Philopteridae) of the Passeriformes (Aves). J. Kansas Entomol. Soc. 1979, 52, 633-640. 
41. Cruickshank, R.H.; Johnson, K.P.; Smith, V.S.; Adams, R.J.; Clayton, D.H.; Page, R.D. Phylogenetic analysis of partial sequences of Elongation Factor $1 \alpha$ identifies major groups of lice (Insecta: Phthiraptera). Mol. Phylogenet. Evol. 2001, 19, 202-215. [CrossRef]

42. Hafner, M.S.; Sudman, P.D.; Villablanca, F.X.; Spradling, T.A.; Demastes, J.W.; Nadler, S.A. Disparate rates of molecular evolution in cospeciating hosts and parasites. Science 1994, 265, 1087-1090. [CrossRef]

43. Barker, S.C.; Whiting, M.; Johnson, K.P.; Murrell, A. Phylogeny of the lice (Insecta, Phthiraptera) inferred from small subunit rRNA. Zool. Scr. 2003, 32, 407-414. [CrossRef]

44. Danforth, B.N.; Ji, S. Elongation factor-1 alpha occurs as two copies in bees: Implications for phylogenetic analysis of EF-1 alpha sequences in insects. Mol. Biol. Evol. 1998, 15, 225-235. [CrossRef]

45. Light, J.E.; Nessner, C.E.; Gustafsson, D.R.; Wise, S.R.; Voelker, G. Remarkable levels of avian louse (Insecta: Phthiraptera) diversity in the Congo Basin. Zool. Scr. 2016, 45, 538-551. [CrossRef]

46. Light, J.E.; Reed, D.L. Multigene analysis of phylogenetic relationships and divergence times of primate sucking lice (Phthiraptera: Anoplura). Mol. Phylogenet. Evol. 2009, 50, 376-390. [CrossRef] [PubMed]

47. Edgar, R.C. MUSCLE: Multiple sequence alignment with high accuracy and high throughput. Nucleic Acids Res. 2004, 32, 1792-1797. [CrossRef]

48. Lanfear, R.; Frandsen, P.B.; Wright, A.M.; Senfeld, T.; Calcott, B. Partition Finder 2: New methods for selecting partitioned models of evolution for molecular and morphological phylogenetic analyses. Mol. Biol. Evol. 2016, 34, 772-773.

49. Ronquist, F.; Teslenko, M.; Van der Mark, P.; Ayres, D.L.; Darling, A.; Höhna, S.; Larget, B.; Liu, L.; Suchard, M.A.; Huelsenbeck, J.P. MrBayes 3.2: Efficient Bayesian phylogenetic and model choice across a large model space. Syst. Biol. 2012, 61, 539-542. [CrossRef] [PubMed]

50. Ronquist, F.; Huelsenbeck, J.P. MrBayes 3: Bayesian phylogenetic inference under mixed models. Bioinformatics 2003, 19, 1572-1574. [CrossRef]

51. Rambaut, A.; Suchard, M.A.; Xie, D.; Drummond, A.J. Tracer v1. 6. 2014. Available online: http:/beast.bio.ed.ac.uk/Tracer (accessed on 5 June 2021).

52. Rambaut, A. FigTree v1.4.2; University of Edinburgh: Edinburgh, UK, 2014.

53. Huelsenbeck, J.P.; Ronquist, F. MRBAYES: Bayesian inference of phylogenetic trees. Bioinformatics 2001, 17, 754-755. [CrossRef] [PubMed]

54. Swofford, D.L. PAUP*: Phylogenetic Analysis Using Parsimony (and Other Methods) 4.0.b5; Sinauer Associates: Sunderland, MA, USA, 2001.

55. R Core Team. R: A Language and Environment for Statistical Computing; R Foundation for Statistical Computing: Vienna, Austria, 2017; Available online: http:/ / www.R-project.org/ (accessed on 5 June 2021).

56. Takano, O.M.; Mitchell, P.S.; Gustafsson, D.R.; Adite, A.; Voelker, G. An assessment of host associations, geographic distributions, and genetic diversity of avian chewing lice (Insecta: Phthiraptera) from Benin. J. Parasitol. 2017, 103, 152-160. [CrossRef] [PubMed]

57. Marini, M.A.; Reinert, B.L.; Bornschein, M.R.; Pinto, J.C.; Pichorium, M.A. Ecological correlates of ectoparasitism on Atlantic Forest birds, Brazil. Rev. Bras. Ornithol. 1996, 4, 93-102.

58. Takano, O.M.; Voelker, G.; Gustafsson, D.R.; Light, J.E. Molecular phylogeny and novel host associations of avian chewing lice (Insecta: Phthiraptera) from South Africa. Syst. Entomol. 2019, 44, 289-304. [CrossRef]

59. Szczykutowicz, A.; Adamski, Z.; Hromada, M.; Tryjanowski, P. Patterns in the distribution of avian lice (Phthiraptera: Amblycera, Ischnocera) living on the great grey shrike Lanius excubitor. Parasitol. Res. 2005, 98, 507-510. [CrossRef] [PubMed]

60. Enout, A.M.J.; Lobato, D.N.C.; Diniz, F.C.; Antonini, Y. Chewing lice (Insecta, Phthiraptera) and feather mites (Acari, Astigmata) associated with birds of the Cerrado in Central Brazil. Parasitol. Res. 2012, 111, 1731-1742. [CrossRef]

61. Girisgin, A.O.; Dik, B.; Girisgin, O. Chewing lice (Phthiraptera) species of wild birds in northwestern Turkey with a new host record. Int. J. Parasitol. Parasites Wildl. 2013, 2, 217-221. [CrossRef]

62. Soto-Patiño, J.; Londoño, G.A.; Johnson, K.P.; Weckstein, J.D.; Avendaño, J.E.; Catanach, T.A.; Sweet, A.D.; Cook, A.T.; Jankowski, J.E.; Allen, J. Composition and distribution of lice (Insecta: Phthiraptera) on Colombian and Peruvian birds: New data on louse-host associations in the Neotropics. Biodiv. Data J. 2018, 6, e21635. [CrossRef]

63. Hernandez, E.A.; Uddameri, V. Standardized precipitation evaporation index (SPEI)-based drought assessment in semi-arid south Texas. Environ. Earth Sci. 2014, 71, 2491-2501. [CrossRef]

64. Western Regional Climate Center. Available online: https://wrcc.dri.edu/ (accessed on 20 September 2015).

65. Carrillo, C.M.; Valera, F.; Barbosa, A.; Moreno, E. Thriving in an arid environment: High prevalence of avian lice in low humidity conditions. Ecoscience 2007, 14, 241-249. [CrossRef]

66. Johnson, K.P.; Whiting, M.F. Multiple genes and the monophyly of Ischnocera (Insecta: Phthiraptera). Mol. Phylogenet. Evol. 2002, 22, 101-110. [CrossRef] [PubMed]

67. Martinů, J.; Sychra, O.; Literák, I.; Čapek, M.; Gustafsson, D.; Štefka, J. Host generalists and specialists emerging side by side: An analysis of evolutionary patterns in the cosmopolitan chewing louse genus Menacanthus. Int. J. Parasitol. 2015, 45, 63-73. [CrossRef] [PubMed]

68. Price, R.D.; Dalgleish, R.C. Myrsidea Waterston (Phthiraptera: Menoponidae) from the Emberizidae (Passeriformes), with descriptions of 13 new species. Zootaxa 2007, 1467, 1-18. [CrossRef]

69. Palma, R.L.; Price, R.D. The species of Myrsidea Waterston (Insecta: Phthiraptera: Menoponidae) from the Galápagos Islands, with descriptions of new taxa. Tuhinga 2010, 21, 135-146. 
70. Valim, M.P.; Weckstein, J.D. A drop in the bucket of the megadiverse chewing louse genus Myrsidea (Phthiraptera, Amblycera, Menoponidae): Ten new species from Amazonian Brazil. Folia Parasit. 2013, 60, 377-400. [CrossRef]

71. Sychra, O.; Kolencik, S.; Palma, R.L. Three new species of Myrsidea (Phthiraptera: Menoponidae) from New Zealand passerines (Aves: Passeriformes). Zootaxa 2016, 4126, 397-410. [CrossRef] [PubMed]

72. Kolencik, S.; Sychra, O.; Papousek, I.; Kuabara, K.M.D.; Valim, M.P.; Literak, I. New species and additional data on the chewing louse genus Myrsidea (Phthiraptera: Menoponidae) from wild Neotropical Passeriformes (Aves). Zootaxa 2018, 4418, $401-431$. [CrossRef]

73. Kolencik, S.; Sychra, O.; Papousek, I.; Literak, I. Where are the species limits? Morphology versus genetics in Neotropical chewing lice of the genus Myrsidea (Phthiraptera: Menoponidae), with descriptions of three new species. Zootaxa 2017, 4324, 161-179. [CrossRef]

74. Lei, L.J.; Chu, X.Z.; Dik, B.; Zou, F.S.; Wang, H.T.; Gustafsson, D.R. Four new species of Myrsidea (Phthiraptera: Amblycera: Menoponidae) from Chinese babblers (Passeriformes: Leiothrichidae, Paradoxornithidae, Timallidae). Zootaxa 2020, 4878, 103-128. [CrossRef]

75. Madrid, R.S.; Sychra, O.; Benedick, S.; Edwards, D.P.; Efeykin, B.D.; Fandrem, M.; Haugassen, T.; Teterina, A.; Tomassi, S.; Tolstenkov, O. Diversity and host associations of Myrsidea chewing lice (Phthiraptera: Menoponindae) in the tropical rainforest of Malaysian Borneo. Int. J. Parasitol. Parasites Wildl. 2020, 13, 231-247. [CrossRef]

76. Arbogast, B.S.; Drovetski, S.V.; Curry, R.L.; Boag, P.T.; Seutin, G.; Grant, P.R.; Grant, B.R.; Anderson, D.J. The origin and diversification of Galapagos Mockingbirds. Evolution 2006, 60, 370-382. [CrossRef]

77. Yuri, T.; Mindell, D.P. Molecular phylogenetic analysis of Fringillidae, New World nine-primaried oscines (Aves: Passeriformes). Mol. Phylogenet. Evol. 2002, 23, 229-243. [CrossRef]

78. Klicka, J.; Johnson, K.P.; Lanyon, S.M. New World Nine-Primaried Oscine relationships: Constructing a mitochondrial DNA framework. Auk 2000, 117, 321-336. [CrossRef]

79. Lahti, D. A case study of species assessment in invasion biology: The Village Weaverbird Ploceus cucullatus. Anim. Biodiv. Conserv. 2003, 26, 45-55.

80. Post, W.; Wiley, J.W. The shiny cowbird in the West Indies. Condor 1977, 79, 119-121. [CrossRef]

81. Foster, M.S. The eggs of three species of Mallophaga and their significance in ecological studies. J. Parasitol. 1969, 55, 453-456. [CrossRef] [PubMed]

82. Najer, T.; Sychra, O.; Kounek, F.; Papousek, I.; Hung, N.M. Chewing lice (Phthiraptera: Amblycera and Ischnocera) from wild birds in southern Vietnam, with descriptions of two new species. Zootaxa 2014, 3755, 419-433. [CrossRef] [PubMed]

83. Najer, T.; Papousek, I.; Adams, C.; Trnka, A.; Quach, V.T.; Nguyent, C.N.; Figura, R.; Literak, I.; Sychra, O. New records of Philopterus (Ischnocera: Philopteridae) from Acrocephalidae and Locustellidae, with description of one new species from Regulidae. Eur. J. Taxon. 2020, 632, 1-37. [CrossRef]

84. Najer, T.; Papousek, I.; Sychra, O.; Sweet, A.D.; Johnson, K.P. Combining nuclear and mitochondrial loci provides phylogenetic information in the Philopterus complex of lice (Psocodea: Ischnocera: Philopteridae). J. Med. Entomol. 2021, 58, 252-260. [CrossRef]

85. Moodi, B.; Aliabadian, M.; Moshaverinia, A.; Kakhki, O.M. New data on the chewing lice (Phthiraptera) of passerine birds in East of Iran. Sci. Parasitol. 2013, 14, 63-68.

86. Valim, M.P.; Palma, R.L. A new genus and two new species of feather lice (Phthiraptera: Ischnocera: Philopteridae) from New Zealand endemic passerines (Aves: Passeriformes). Zootaxa 2015, 3926, 480-498. [CrossRef]

87. Valim, M.P.; Kuabara, K.M.D. The feather louse genus Mulcticola Clay et Meinertzhagen, 1938 (Phthiraptera: Philopteridae) from Brazil, with descriptions of five new species and catalogue for species described in the genus. Fol. Parasitol. 2015, 62, 36. [CrossRef]

88. Gustafsson, D.R.; Bush, S.E. Descriptions of seven new species of Brueelia Keler 1936 (Phthiraptera: Ischnocera: Philopteridae) from North American sparrows (Aves: Passeriformes: Passerellidae), and review of host use by Brueelia vulgata. J. Nat. Hist. 2020, 54, 2071-2112. [CrossRef]

89. Smith, V.S. Avian louse phylogeny (Phthiraptera: Ischnocera): A cladistic study based on morphology. Zool. J. Linn. Soc. 2001, 132, 81-144. [CrossRef]

90. Bush, S.E.; Weckstein, J.D.; Gustafsson, D.R.; Allen, J.; Diblasi, E.; Shreve, S.M.; Boldt, R.; Skeen, H.R.; Johnson, K.P. Unlocking the black box of feather louse diversity: A molecular phylogeny of the hyper-diverse genus Brueelia. Mol. Phylogenetics Evolut. 2016, 94, 737-751. [CrossRef] [PubMed]

91. Gustafsson, D.R.; Bush, S.E. Morphological revision of the hyperdiverse Brueelia-complex (Insecta: Phthiraptera: Ischnocera: Philopteridae) with new taxa, checklists and generic key. Zootaxa 2017, 4313, 1-433. [CrossRef]

92. Johnson, K.P.; Adams, R.J.; Clayton, D.H. The phylogeny of the louse genus Brueelia does not reflect host phylogeny. Biol. J. Linn. Soc. 2002, 77, 233-247. [CrossRef]

93. Cicchino, A.C. Notas sinonimias [sic] y hospedatorias referentes a las especies del genero Brueelia Keler 1936 (Phthiraptera Philopteridae) que parasitan Passeriformes de lafamilia Mimidae (Aves). Rev. Soc. Entomol. Arg. 1986, 44, 74-76.

94. Johnson, K.P.; Moyle, R.G.; Witt, C.C.; Faucett, R.C.; Weckstein, J.D. Phylogenetic relationships in the louse genus Penenirmus based on nuclear (EF-1 a) and mitochondrial (COI) DNA sequences. Syst. Entomol. 2001, 26, 491-497. [CrossRef]

95. Geist, R.M. Notes on the infestation of wild birds by Mallophaga. Ohio J. Sci. 1935, 35, 93-100.

96. Peters, H.S. A list of external parasites from birds of the eastern part of the United States. Bird-Banding 1936, 7, 9-27. [CrossRef] 
97. Mey, E. Zur Taxonomie, Verbreitung und parasitophyletischer Evidenz des Philopterus-Komplexes (Insecta, Phthiraptera, Ischnocera). Ornithol. Anz. 2004, 43, 149-203.

98. Clay, T. Revisions of Mallophaga genera. Degeeriella from the Falconiformes. Bull. Br. Mus. Nat. Hist. Entomol. 1958, 7, 121-207.

99. Johnson, K.P.; Weckstein, J.D.; Witt, C.C.; Faucett, R.C.; Moyle, R.G. The perils of using host relationships in parasite taxonomy: Phylogeny of the Degeeriella complex. Mol. Phylogenet. Evol. 2002, 23, 150-157. [CrossRef]

100. Meyer, M.J.; Price, R.D.; Johnson, K.P. A new species of Picicola Clay and Meinertzhagen, 1938 (Phthiraptera: Ischnocera) parasitic on the Rufous-sided Broadbill (Passeriformes: Eurylaimidae) in Ghana. Zootaxa 2008, 1762, 63-68. [CrossRef] 